\title{
Analisis Perbandingan Efisiensi Bank Umum Konvensional dan Bank Umum Syariah di Indonesia
}

\author{
Azizah Kartika Rahmawati ${ }^{1 *}$, S.R. Kartika Sari ${ }^{2}$, Herry Hermawan ${ }^{3}$ \\ 1, 2,3 Universitas Merdeka Madiun \\ 1'Azizahkartikar@gmail.com, 2syarifah@unmer-madiun.ac.id, \\ 3heryhermawan@unmer-madiun.ac.id \\ ${ }^{*}$ Penulis Korespondensi
}

\begin{abstract}
The purpose of this study was to determine the level of efficiency between conventional commercial banks and Islamic commercial banks. The sampling technique used in this study was purposive sampling by taking state-owned banks and Islamic commercial banks with the highest assets. Efficiency measurement in this study uses the Data Envelopment Analysis (DEA) method. The results of this study indicate that there are differences in efficiency between conventional commercial banks and Islamic commercial banks. Overall, each bank has an efficiency level of $93.67 \%$ (conventional commercial banks) and 99.99\% (Islamic commercial banks). These results indicate that Islamic commercial banks are more efficient than conventional commercial banks.
\end{abstract}

Keywords: efficiency, data envelopment analysis, conventional banks, Islamic banks

\begin{abstract}
Abstrak
Tujuan dari penelitian ini adalah untuk mengetahui tingkat efisiensi antara bank umum konvensional dan bank umum syariah. Teknik pengambilan sampel yang digunakan dalam penelitian ini adalah purposive sampling dengan mengambil bank BUMN dan bank umum syariah yang memiliki asset tertinggi. Pengukuran efisiensi dalam penelitian ini menggunakan metode Data Envelopment Analysis (DEA). Variabel input yang digunakan dalam penelitian adalah Aktiva Tetap, Simpanan, dan Biaya Tenaga Kerja, sedangkan variabel outputnya dalah Total Kredit dan Pendapatan Operasional. Hasil dari penelitian ini menunjukkan bahwa terdapat perbedaan efisiensi antara bank umum konvensional dan bank umum syariah selama periode 2013-2017. Secara keseluruhan masing-masing bank memperoleh tingkat efisiensi sebesar 93,67\% (bank umum konvensional) dan 99,99\% (bank umum syariah). Hasil tersebut menunjukkan bahwa bank umum syariah lebih efisien dibandingkan bank umum konvensional.
\end{abstract}

Kata Kunci: efisiensi, data envelopment analysis, bank konvensional, bank syariah 


\section{PENDAHULUAN}

Penilaian efisiensi bank menjadi sangat penting dengan kondisi seperti ini, karena efisiensi merupakan gambaran kinerja suatu bank sekaligus menjadi faktor yang harus diperhatikan bank untuk bertindak rasional dalam meminimumkan tingkat risiko yang dihadapi dalam menghadapi kegiatan operasinya. Analisis mengenai efisiensi menjadi sangat penting karena penghimpunan dan peyaluran pembiayaan yang ekspansif tanpa memperhatikan faktor efisiensi akan berpengaruh terhadap profitabilitas bank yang bersangkutan (Muharam \&Pusvitasari, 2007).

Efisiensi merupakan salah satu kinerja yang mendasari seluruh kinerja sebuah organisasi. Kemampuan menghasilkan output yang maksimal dengan input yang ada merupakan ukuran kinerja yang diharapkan. Pada saat pengukuran efisiensi dilakukan, bank dihadapkan pada kondisi bagaimana mendapatkan tingkat output yang optimal dengan tingkat input yang ada, atau mendapatkan tingkat input yang minimum dengan tingkat output tertentu. Dengan diidentifikasikannya alokasi input dan output, dapat dianalisa lebih jauh untuk melihat penyebab ketidakefisiensian.

Efisiensi merupakan salah satu tujuan utama yang ingin dicapai oleh para pemangku kepentingan (stakeholder). Tujuan utama dari stakeholder adalah untuk membantu manajemen perusahaan dalam meningkatkan nilai efisiensi sebagai dampak dari aktivitas-aktivitas yang dilakukan dan meminimalkan kerugian yang mungkin muncul. Keberadaan stakeholder akan sangat mempengaruhi pola pikir dan persepsi manajemen terhadap kepentingan praktik akuntansi perusahaan (Chariri, 2007).

Untuk mengukur efisiensi perbankan tidak hanya dapat dilakukan dengan melihat perbandingan indikator kinerja perbankan dan rasio keuangan saja. Pengukuran efisiensi perbankan yang dilakukan dengan menggunakan rasio-rasio keuangan, seperti rasio Biaya Operasional terhadap Pendapatan Operasional (BOPO) memiliki beberapa kelemahan. Beberapa kelemahan tersebut ialah sangat sulit diinterpresentasikan, karena pengurangan biaya belum tentu menandakan efisiensi. Pengurangan biaya sering kali berdampak pada kualitas produk dan jasa yang selanjutnya berdampak pada pendapatan. Sehingga terdapat beberapa metode lain yang digunakan dalam mengukur efisiensi yaitu metode non-parametrik dengan Data Envelopment Analysis (DEA) dan metode parametrik dengan Stochasic Frountier Approach (SFA). Kedua metode ini dianggap lebih baik daripada metode dengan menggunakan rasio keuangan.

Terdapat beberapa penelitian yang telah melakukan penelitian tingkat efisiensi bank syariah dengan bank konvensional. Ferrari dan Sudarsono (2011) dengan menggunakan DEA menemukan bahwa tingkat efisiensi di bank syariah cukup beragam. Bahkan pada aspek intermediari, bank konvensional justru menunjukkan tingkat efisiensi yang lebih baik.

Ramly \& Hakim (2017) dengan menggunakan DEA dua tahap, dimana tahap pertama menggunakan DEA untuk mengukur efisiensi masing-masing bank. Selanjutnya tahap kedua menggunakan uji t untuk membandingkan efisiensi diantara keduanya. Mereka menemukan bahwa terdapat perbedaan tingkat efisiensi antara bank konvensional dengan bank syariah. Namun, hasil berbeda didapat oleh Sunarsih (2017), dimana pada penelitiannya tidak 
menemukan perbedaan tingkat efisensi antara bank syariah dengan bank konvensional. Temuan Sunarsih menunjukkan bahwa baik bank syariah maupun bank konvensional memiliki tingkat efisiensi yang secara rerata sama.

Pambuko (2016) menggunakan DEA dua tahap, yaitu pada tahap pertama menggunakan DEA dan tahap kedua menggunakan regresi tobit. Penelitiannya menemukan bahwa bank syariah yang lebih kecil memiliki tingkat efisiensi lebih tinggi dibandingkan bank syariah yang besar. Hasil ini serupa dengan temuan Cahyaningsih dkk (2017) dengan menggunakan alata analisis DEA menemukan bahwa bank syariah Mandiri memiliki tingkat efisiensi lebih rendah jika dibandingkan dengan bank syariah Bukopin dan bank BNI syariah. Hasil ini memberikan masukan bagi manajemen untuk mampu meningkatkan efisiensinya.

Alur proses transformasi variabel input yang dipilih menjadi bentuk output ini adalah seberapa besar fungsi bank dilihat dari seberapa besar jumalah simpanan yang mampu dihimpun oleh bank untuk disalurkan kembali kemasyarakat dalam bentuk kredit, sehingga akan menghasilkan pendapatan operasonal dari hasil penyaluran kredit tersebut. Biaya Tenaga Kerja merupakan sumber daya input yang penting dalam menjalankan kegiatan operasional bank karena tenaga kerja sebagai pelaku kegiatan operasional bank. Pengukuran dalam efisiensi ini menghubungkan efisiensi terhadap tingkat produksi. Analisis ini selanjutnya akan menghasilkan perumusan frontier interaksi antara input dalam mempengaruhi jumlah output yang dihasilkan (Purwanto, 2011)

Melihat pada berbagai temuan penelitian yang menunjukkan perbedaan hasil ketika melakukan perbandingan tingkat efisiensi antara bank syariah dengan bank konvensional, maka terlihat bahwa masih ada kesenjangan penelitian yang dapat diteliti lebih lanjut mengenai tingkat efisiensi di kedua bank tersebut. Sehingga, hal ini akan mampu memberikan kontribusi signifikan dalam penelitian mengenai pengukuran tingkat efisiensi antara perbankan syariah dengan perbankan konvensional.

Oleh karenanya, tujuan dari penelitian ini adalah untuk mengukur perbandingan efisiensi perbankan syariah dengan perbankan konvensional di Indonesia. Dengan adanya penelitian ini, maka akan dapat menganalisis tingkat perbandingan efisiensi perbankan syariah dan perbankan konvensional di Indonesia pada tahun 2013-2017.

\section{METODE}

Jenis data yang digunakan dalam penelitian ini adalah data sekunder dari laporan keuangan tahunan perusahaan yang telah dipublikasikan. Populasi dalam penelitian ini adalah bank konvensional dan bank syariah yang terdaftar di Bank Indonesia selama periode 2013-2017. Pengambilan sampel dipilih dengan menggunakan metode purposive sampling yang didasarkan pada kriteria yaitu: Pertama, bBank umum konvensional dan bank umum syariah yang beroperasi di Indonesia yang berskala nasional selama periode pengamatan 2013-2017. Kedua, Bank umum konvensional dan bank umum syariah tersebut melaporkan laporan keuangan dan catatan atas laporan tahun 2013 sampai dengan 2017 secara berturut-turut. Ketiga, Bank umum konvensional dan bank umum syariah yang bermata uang rupiah (Rp.). Keempat, Bank umum konvensional dan bank umum syariah 
yang sudah memenuhi syarat delisting. Kelima, Bank umum konvensional dan bank umum syariah yang tidak mengalami kerugian. Keenam, Bank umum konvensional dan bank umum syariah yang sudah diaudit. Ketujuh, merupakan Bank BUMN dan bank syariah yang memiliki asset tertinggi. Dengan demikian yang di anggap memenuhi kriteria di atas untuk dijadikan sempel Bank Umum Konvensional dan Bank Umum Syariah adalah Bank Rakyat Indonesia, Bank Mandiri, Bank Negara Indonesia, Bank Tabungan Negara, Bank Muamalat Indonesia, Bank Mandiri Syariah, BRI Syariah, dan BNI Syariah.

Variabel yang digunakan dalam penelitian ini adalah variabel input meliputi: Aktiva Tetap, Simpanan, dan Biaya Tenaga Kerja serta variabel output: Total Kredit dan Pendapatan Operasional. Teknik analisis data yang digunakan adalah metodologi non-parametrik, dengan metodologi yang dikenal dengan istilah Data Envelopment Analysis (DEA). DEA menghitung efisiensi teknis (Technical Efficiency) untuk seluruh unit. Skor efisiensi untuk setiap unit adalah relatif, tergantung pada tingkat efisiensi dari unit-unit lainnya di dalam sampel. Setiap unit dalam sampel dianggap memiliki tingkat efisiensi yang tidak negatif, dan nilainya antara 0 hingga 1, dimana satu menunjukkan efisiensi yang sempurna. Kemudian unit-unit yang memiliki nilai satu ini digunakan dalam membuat envelope untuk frontier efisiensi. Unit-unit lainnya yang ada di dalam envelope menunjukkan tingkat inefisiensi (Hadad dkk, 2003). Efisiensi teknik perbankan diukur dengan menghitung rasio antara output dan inputnya. DEA akan menghitung bank yang menggunkan input $n$ untuk menghasilkan output $m$ yang berbeda (Huda \& Nasution, 2014).

$h s=\frac{\sum_{i-1}^{m} u i y i s}{\sum_{j-1}^{n} v j x j s}$

Dimana:

Hs = efisiensi bank s

$\mathrm{M}$ = output bank s yang diamati

$\mathrm{N}=$ input bank s yang diamati

Yis = jumlah output $i$ yang diproduksi oleh bank $\mathrm{s}$

Xjs $=$ jumlah input $\mathrm{j}$ yang diproduksi oleh bank $\mathrm{s}$

$\mathrm{Ui}=$ bobot output i yang dihasilkan oleh bank $\mathrm{s}$

$\mathrm{Vj}$ = bobot input $\mathrm{j}$ yang digunkan oleh bank $\mathrm{s}$ dan i dihitung dari 1 ke $\mathrm{m}$ serta $\mathrm{j}$ hitung dari 1 ke $n$

Persamaan diatas menunjukkan adanya penggunaan satu variabel input dan satu output. Rasio efisiensi ( $h s$ ), kemudian dimaksimumkan dengan kendala sebagai berikut (Sutawijaya \& Lestari, 2009):

Memaksimumkan $h_{s}=\frac{\sum_{i-1}^{m} u i \text { yis }}{\sum_{j-1}^{n} v j \times j s} \leq 1 ; \mathrm{r}=, . ., \mathrm{N}$

Dimana $u i$ dan $v j \geq 0$

$\mathrm{N}$ mewakili jumlah bank dalam sampel dan $r$ merupakan jenis bank yang dijadikan sampel dalam penelitian. Pertidaksamaan pertama menjelaskan bahwa adanya rasio untuk unik kegiatan ekonomi (UKE) lain tidak lebih dari 1, sementara pertidaksamaan kedua 
berbobot positif. Angka rasio akan bervariasi antara 0 sampai dengan 1. Bank dikatakan efisien apabila memiliki angka rasio mendekati 1 atau 100 persen, begitu pula sebaliknya apabila mendekati 0 menunjukkan efisiensi bank yang semakin rendah. Pada DEA, setiap bank dapat menentukan bobotnya masing-masing dan menjamin bahwa pembobotannya yang dipilih akan menghasilkan ukuran kinerja yang terbaik (Sutawijaya \& Lestari, 2009; Aini, 2014).

\section{HASIL DAN PEMBAHASAN}

Berdasarkan hasil analisis deskrptif yang disajikan pada Tabel 1 dapat dijelaskan: Pertama, nilai Aktiva Tetap bank umum konvensional memiliki nilai minimum sebesar 14,24\% (Bank BTN tahun 2013), sedangkan nilai Aktiva Tetap bank umum konvensional maxsimum sebasar 17,42\% (Bank Mandiri tahun 2017). Mean Aktiva Tetap bank umum konvensional adalah sebesar 16,1558 dengan standart deviasi sebesar 0,91904. Kedua, nilai Simpanan bank umum konvensional memiliki nilai minimum sebesar 17,69\% (Bank BTN tahun 2013), sedangkan nilai simpanan bank umum konvensional maxsimum sebesar 20,55\% (Bank BRI tahun 2017). Mean simpanan bank umum konvensional adalah sebesar 19,5525 dengan standart deviasi sebesar 1,01142. Ketiga, nilai Biaya Tenaga Kerja bank umum konvensional memiliki nilai minimum sebesar 14,05\% (Bank BTN tahun 2014), sedangkan nilai Biaya Tenaga Kerja bank umum konvensional maxsimum sebesar 16,83\% (Bank BRI tahun 2017). Mean simpanan bank umum konvensional adalah sebesar 15.6758 dengan standart deviasi sebesar 0,92209. Keempat, nilai Total Kredit bank umum konvensional memiliki nilai minimum sebesar 18.60\% (Bank BTN tahun 2013), sedangkan nilai Total Kredit bank umum konvensional maxsimum sebesar 20,68\% (Bank BRI tahun 2016). Mean simpanan bank umum konvensional adalah sebesar 19,9091 dengan standart deviasi sebesar 0.67075. Kelima, nilai Pendapatan Operasional bank umum konvensional memiliki nilai minimum sebesar 14.84\% (Bank BRI tahun 2015), sedangkan nilai Pendapatan Operasional bank umum konvensional maxsimum sebesar 18.36\% (Bank BTN tahun 2017). Mean Pendapatan Operasional bank umum konvensional adalah sebesar 16,2992 dengan standart deviasi sebesar 0.69216 .

Tabel 1. Hasil Analisis Deskriptif Bank Umum Konvensional

\begin{tabular}{lccccc}
\hline & N & Minimum & Maximum & Mean & Std. Deviation \\
\hline Aktiva Tetap & 20 & 14.24 & 17.42 & 16.1558 & .91904 \\
Simpanan & 20 & 17.69 & 20.55 & 19.5525 & 1.01142 \\
Biaya Tenaga Kerja & 20 & 14.05 & 16.83 & 15.6758 & .92209 \\
Total Kredit & 20 & 18.60 & 20.68 & 19.9091 & .67075 \\
Pendapatan Operasi & 20 & 14.84 & 18.36 & 16.2992 & .69216 \\
Valid N (listwise) & 20 & & & & \\
\hline
\end{tabular}

Sumber: hasil olahan data 
Berdasarkan hasil analisis deskrptif yang disajikan pada tabel 2 dapat dijelaskan sebagai berikut: Pertama, nilai Aktiva Tetap bank umum syariah memiliki nilai minimum sebesar 11,97\% (Bank BNI syariah tahun 2013), sedangkan nilai Aktiva Tetap bank umum syariah maxsimum sebesar 20,48\% (Bank Mandiri Syariah tahun 2013). Mean Aktiva Tetap bank umum syariah adalah sebesar 14,1366 dengan standart deviasi sebesar 2,36479. Kedua, nilai Simpanan bank umum syariah memiliki nilai minimum sebesar 14,39\% (Bank BNI syariah tahun 2013), sedangkan nilai Simpanan bank umum syariah maxsimum sebesar 16,27\% (Bank Mandiri Syariah tahun 2017). Mean Simpanan bank umum syariah adalah sebesar 15,4404 dengan standart deviasi sebesar 0.54175. Ketiga, nilai Biaya Tenaga Kerja bank umum syariah memiliki nilai minimum sebesar 10,42\% (Bank BRI syariah tahun 2013), sedangkan nilai Biaya Tenaga Kerja bank umum syariah maxsimum sebesar 14,29\% (Bank Mandiri Syariah tahun 2017). Mean Biaya Tenaga Kerja bank umum syariah adalah sebesar 12,8781 dengan standart deviasi sebesar 1,31810.

Tabel 2. Hasil Analisis Deskriptif Bank Umum Syariah

\begin{tabular}{lccccc}
\hline & N & Minimum & Maximum & Mean & Std. Deviation \\
\hline AKTIVA TETAP & 20 & 11.97 & 20.48 & 14.1366 & 2.36479 \\
SIMPANAN & 20 & 14.39 & 16.27 & 15.4404 & .54175 \\
BIAYA TENAGA KERJA & 20 & 10.42 & 14.29 & 12.8781 & 1.31810 \\
TOTAL KREDIT & 20 & 15.40 & 17.84 & 16.6527 & .70626 \\
PEND. OPERASI & 20 & 11.83 & 15.80 & 13.7566 & 1.53624 \\
Valid N (listwise) & 20 & & & & \\
\hline
\end{tabular}

Sumber: hasil olahan data

Keempat, nilai Total Kredit bank umum syariah memiliki nilai minimum sebesar 15,40\% (Bank Muamalat tahun 2014), sedangkan nilai Total Kredit bank umum syariah maxsimum sebesar 17,84\% (Bank Muamalat tahun 2017). Mean Total Kredit bank umum syariah adalah sebesar 16,6527 dengan standart deviasi sebesar 0.70626. Kelima, nilai Pendapatan Operasional bank umum syariah memiliki nilai minimum sebesar 11,83\% (Bank BNI syariah tahun 2015), sedangkan nilai Pendapatan Operasional bank umum syariah maxsimum sebesar 15,80\% (Bank Mandiri syariah tahun 2017). Mean Pendapatan Operasional bank umum syariah adalah sebesar 13,7566 dengan standart deviasi sebesar 1.53624.

Tabel 3 menunjukkan hasil analisis tingkat efisiensi menggunakan metode DEA frontier dengan variabel input berupa Aktiva Tetap, Simpanan dan Biaya Tenaga Kerja serta variabel output berupa Total Kredit dan Pendapatan Operasional menunjukkan bahwa rata-rata efisiesni pada bank umum konvensional adalah sebesar 0,93674541 atau 93,67\%. Nilai tersebut menunjukkan efisiensi relatif baik (nilai efisiensi mendekati 1 menunjukan semakin efisien). Tingkat efisiensi pada bank umum konvensional yang tertinggi yaitu mencapai 0.98874985 atau 98,87\% pada Bank BNI, sedangkan efisiensi terendah yaitu sebesar 0.87806106 atau $87,80 \%$ pada Bank BRI. 
Tabel 3. Hasil Analisis Efisiensi Metode DEA Bank Umum Konvensional

\begin{tabular}{|c|c|c|}
\hline No. & Nama Bank & Tingkat Efisiensi \\
\hline 1 & BRI & 0.87806106 \\
\hline 2 & Mandiri & 0.90188193 \\
\hline 3 & BNI & 0.98874985 \\
\hline 4 & BTN & 0.97828880 \\
\hline \multicolumn{2}{|c|}{ Mean efisiensi: } & 0.93674541 \\
\hline
\end{tabular}

Sumber: data sekunder yang diolah

Tabel 4 menunjukkan hasil analisis tingkat efisiensi menggunakan metode DEA frontier dengan variabel input berupa Aktiva Tetap, Simpanan dan Biaya Tenaga Kerja serta variabel output berupa Total Kredit dan Pendapatan Operasional menunjukkan bahwa rata-rata efisiensi pada bank umum syariah khususnya bank syariah yang memiliki asset tertinggi adalah sebesar 0,9999039 atau 99,9\%. Nilai tersebut menunjukkan efisiensi relatif baik (nilai efisiensi mendekati 1 menunjukan semakin efisien). Tingkat efisiensi pada bank umum Syariah yang tertinggi yaitu mencapai 0.99999183 atau 99,91\% pada Bank Mandiri syariah, sedangkan efisiensi terendah yaitu sebesar 0.99998930 atau 99,89\% pada Bank BRI syariah.

Tabel 4. Hasil Analisis Efisiensi Metode DEA Bank Umum Syariah

\begin{tabular}{clc}
\hline No. & \multicolumn{1}{c}{ Nama Bank } & Tingkat Efisiesni \\
\hline 1 & Mandiri Syariah & 0.99999183 \\
2 & Muamalat & 0.99999087 \\
3 & BRI Syariah & 0.99998930 \\
4 & BTN Syariah & 0.99998958 \\
Mean & efisiensi: & 0.99999039 \\
\hline
\end{tabular}

Sumber: data sekunder yang diolah

Hasil analisis mendapatkan bahwa rata-rata efisiensi pada bank umum konvensional selama periode penelitian diperoleh sebesar 0,93674541 atau 93,67\%, dan rata-rata efisiensi bank umum syariah diperoleh sebesar 0,9999039 atau 99,9\%. Hasil tersebut menyatakan bahwa bank umum syariah lebih efisien dibandingkan dengan bank umum konvensional. Meskipun rata-rata efisiensi bank umum konvensional dinyatakan relatif baik, namun bank umum syariah memiliki nilai yang mendekati 100\%, berbeda dengan bank umum konvensional yang hanya memiliki rata-rata 93,67\%.

Hasil dari penelitian ini menunjukkan bahwa, antara bank umum konvensional dan bank umum syariah terdapat adanya perbedaan efisiensi. Bank umum syariah menujukkan nilai efisiensi yang lebih tinggi dibandingkan bank umum konvensional. Bank-bank besar seperti bank umum konvensional justru memiliki tingkat efisiensi yang kurang baik, sedangkan 
bank-bank dengan kapasitas kecil seperti bank syariah justru memiliki tingkat efisiensi yang tinggi. Hal ini disebabkan karena output yang dikeluarkan pada bank konvensional relatif besar serta perubahan anggaran atau realisasi biaya yang di keluarkan pada bank umum konvensional cenderung relatif tinggi dibandingkan bank umum syariah.

Ketidakefisiensian output terjadi pada total kredit atau pembiayaan dan pendapatan. Pertama, jumlah pembiayaan lebih kecil dari target yang telah ditentukan, hal tersebut dapat terjadi karena adanya pemborosan anggaran yang dikeluarkan, sehingga dapat mempengaruhi target yang telah ditentukan, serta prinsip kehati-hatian oleh bank sebelum memberikan kredit. Namun kehati-hatian yang dilakukan oleh bank tidak menghambat target yang ditentukan. Cara agar tidak menghambat target yang ditentukan yaitu dengan menurunkan tingkat suku bunga kredit, hal ini dilakukan agar banyak masyarakat baik perorangan atau perseroan mengajukan pembiayaan, sehingga target pembiayaan dapat tercapai dalam pembangunan ekonomi. Kedua, jumlah pendapatan masih belum sesuai dengan apa yang diharapkan, langkah yang digunakan yaitu dengan meningkatkan pendapatan bunga dan pendapatan operasional. Perbaikan kualitas SDM harus dilakukan untuk meningkatkan pendapatan operasional dan pendapatan operasional lainnya, karena hal ini berhubungan dengan produktivitas kerja dan kreativitas karyawan untuk menghasilkan output yang maksimal.

Industri perbankan syariah dinilai lebih efisien dibandingkan perbankan konvensional, dilihat dari sisi teknis operasional dan tahapan penjaringan dana pihak ketiga (DPK) hingga penyaluran dana pembiayaan syariah bagi masyarakat. Salah satu bukti bahwa bank syariah lebih efisien ditunjukkan oleh rasio pembiayaan dibandingkan dana pihak ketiga, FDR perbankan syariah ternyata lebih tinggi dibandingkan rasio penyaluran kredit terhadap DPK (loan to deposit ratio, LDR) perbankan konvensional. Lebih tingginya efisiensi bank umum syariah yang disebabkan karena perbankan syariah memiliki porsi dana murah lebih sedikit dibandingkan perbankan konvensional, Sedikitnya porsi dana murah pada perbankan syariah berdampak pada tingginya biaya dana (cost of fund) yang harus ditanggung. Selain itu, skala usaha bank syariah akan mampu menentukan tingkat efisiensi suatu perbankan. Edward \& Anwar (2015) menemukan bahwa semakin besar skala usaha bank syariah, maka akan semakin efisiensi bank syariah tersebut.

Hasil analisis ini sesuai dengan penelitian sebelumnya yang dilakukan oleh Novandra (2017) bahwa terdapat perbedaan tingkat efisiensi antara bank umum konvensional dan bank umum syariah. Dengan metode Data Envelopment Analysis menunjukkan bahwa bank umum syariah lebih efisien dibandingkan dengan bank umum konvensional. Bank umum konvensional dikatakan kurang atau tidak efisien karena terdapat pemborosan penggunaan output, sehingga belum mampu memanfaatkan potensi kemampuan berproduksi yang dimiliki secara optimal.

\section{SIMPULAN}

Penelitian ini bertujuan untuk membandingkan tingkat efisiensi antara perbankan konvensional dan perbankan syariah dengan pendekatan non-parametrik menggunakan Data Envelopment Analysis (DEA). Temuan penelitian menunjukkan bahwa terdapat tiga 
bank umum konvensional yang memiliki nilai rata-rata mendekati angka 1 atau dikatakan hampir memenuhi standar efisiensi, yaitu Bank BNI, Bank BTN, dan Bank Mandiri. Sedangkan Bank BRI hanya memiliki tingkat efisiensi rendah. Hasil rata-rata efisiensi yang diperoleh bank umum konvensional menunjukkan bahwa bank tersebut dikatakan kurang efisien, karena rata-rata yang diperoleh kurang dari satu. Penyebab tidak atau kurangnya efisiensi pada bank umum konvensional karena anggaran atau realisasi biaya yang di keluarkan pada bank tersebut relatif besar.

Pada bank umum syariah hampir seluruhnya memiliki tingkat efisiensi yang baik. Hasil rata-rata yang diperoleh bank umum syariah menunjukkan bahwa bank tersebut dikatakan efisien, karena rata-rata yang diperoleh mendekati angka satu atau memenuhi standart efisiensi. Semakin besar anggaran yang dikeluarkan akan semakin tidak efisien begitupun sebaliknya. Jadi terdapat perbedaan efisiensi antara bank umum konvensional dan bank umum syariah, secara keseluruhan masing-masing memperoleh tingkat efisiensi yang berbeda, dimana bank umum syariah lebih tinggi dibandingkan bank umum konvensional. Hasil tersebut menunjukkan bahwa bank umum syariah dikatakan lebih efisien dibandingkan bank umum konvensional.

\section{PUSTAKA ACUAN}

Aini, A. N. (2014). Analisis Perbandingan Efisiensi Bank Umum Konvensional Dan Bank Umum Syariah Dengan Metode Data Envelopment Analysis (DEA) (Periode tahun 20082012). Skripsi Tidak Dipublikasikan. Surakarta: Universitas Muhammadiyah Surakarta.

Cahyaningsih, P., Purnomo, D., Harun., \& Harmarini, M. I. (2017). Kinerja Beberapa Bank Syariah Berdasar Tingkat Efisiensi Melalui Pengukuran DEA. Cakrawala: Jurnal Studi Islam, XII(2), 133-140.

Chariri, A. (2007). Teori Akuntansi. Semarang: Badan Penerbit Universitas Diponegoro.

Edward, Y. M., \& Anwar, Z. A. (2015). Analisis Efisiensi Perbankan Syariah di Indonesia (periode 2010-2013). Dinamika Ekonomi \& Bisnis, 12(1), 99-108.

Ferrari, N., \& Sudarsono, H. (2011). Tingkat Efisiensi Perbankan Syariah dan Konvensional dengan Menggunakan Data Envelopment Analysis. Jurnal Ekonomi \& Keuangan Islam, 1(2), 141-148.

Hadad, M. D., Santoso, W., Mardanugraha, E., \& Ilyas, D. (2003). Pendekatan Parametrik Efisiensi Perbankan Indonesia. Working Paper. Jakarta: Bank Indonesia.

Huda, N., \& Nasution, M. E. (2014). Current Issues Lembaga Keuangan Syariah. Jakarta: Kencana.

Muharam, H., \& Pusvitasari, R. (2007). Analisis Perbandingan Efisiensi Bank Syariah di Indonesia Dengan Metode Data Envelopment Analysis (periode Tahun 2005). Jurnal Ekonomi dan Bisnis Islam, 2(3), 80-166.

Novandra, R. (2017). Analisis Perbandingan Efisiensi Perbankan Syariah dan Konvensional di Indonesia: Jurnal Ekonomi dan Pembangunan, 22(2), 183-193.

Pambuko, Z. B. (2016). Determinan Tingkat Efisiensi Perbankan Syariah di Indonesia: Two Stages Data Envelopment Analysis. Cakrawala, XI(2), 178-194. 
Purwanto, R. (2011). Analisis Perbandingan Efisiensi Bank Umum Konvensional (BUK) dan Bank Umum Syariah (BUS) di Indonesia dengan Metode Data Envelopment Analysis (DEA) (Periode 2006-2010). Skripsi Tidak Dipublikasikan. Semarang: Universitas Diponegoro.

Ramly, A. R., \& Hakim, A. (2017). Pemodelan Efisiensi Bank di Indonesia: Perbandingan antara Bank Syariah dan Bank Konvensional. Esensi: Jurnal Bisnis dan Manajemen, 7(2), 131-148.

Sunarsih. (2017). Analisis Perbandingan Tingkat Efisiensi Perbankan Syariah dan Konvensional di Indonesia. Asy-Syir'ah: Jurnal Ilmu Syariah dan Hukum, 51(1), 225-290.

Sutawijaya, A., \& Lestari, E. P. (2009). Efisiensi Teknik Perbankan Indonesia Pasca Krisis Ekonomi: Sebuah Studi Empiris Penerapan DEA. Jurnal Ekonomi Pembangunan, 10(1), 49-67. https://doi.org/10.23917/jep.v10i1.808. 